\title{
The Ancient Locality Syndianna with Charophytes in the Northern Israel
}

\author{
S. Barinova ${ }^{1, *}$, R. Romanov ${ }^{2}$ \\ ${ }^{1}$ Institute of Evolution, University of Haifa, Israel \\ ${ }^{2}$ Central Siberian Botanical Garden of the Siberian Branch of the Russian Academy of Sciences, Russia
}

Copyright $\bigcirc 2016$ by authors, all rights reserved. Authors agree that this article remains permanently open access under the terms of the Creative Commons Attribution License 4.0 International License

\begin{abstract}
The ancient locality of charophytes is described from the Sindyanna pool, Upper Jordan River Basin, Golan Heights region of Israel. The associated algal diversity was revealed, and ecological assessment of aquatic environment was obtained with bio-indication methods. Algal community was represented by fifty four species one of which is charophyte macroalga Chara globularis Thuiller. The Chara was found in mass growths in the studied pool. Bio-indication and chemical variables characterize the pool environment as eutrophic, low- to middle organically polluted, belonging to water quality Class III. Fifty five species-indicators in community reflect water quality as fresh, temperate temperature, low- to middle alkaline, and enough saturated with oxygen. Seasonality of algal community and water quality show a higher organic pollution in summer caused by livestock grazing impact. Anoxia, high water $\mathrm{pH}$, increasing of nitrates enrichments in dry period together with decreasing of species richness and index WESI which reflect some of toxicity impact, can be result of water pollution. We recommend for monitoring the ancient Sindyanna natural aquatic object in the Upper Jordan River Basin, and Chara globularis as indicator-species of ecosystem resistance to pollution.
\end{abstract}

Keywords Chara, Ecology, Bio-indication, Pool, Golan Heights, Israel

\section{Introduction}

The charophytes (Charophyta, Charales) are the sister group of embryophytes. The species of Chara might be very important components of vegetation in several types of freshwater and saline continental water bodies and inland hyposaline seas. They provide habitat and food for animals, remove and store the nutrients and pollutants from water. They could control their environment thus stabilizing the state of water ecosystems. The species of Chara might be used as a bio-indicator of ecosystem state, water quality, and ecosystem recovery and reservoir management efficiency. Its diversity is very important indicators of ecological state of aquatic ecosystem in water bodies of the Natural Reserves. Diversity of this group in the Eastern Mediterranean is up to last year's studied in initial stage. The Chara species prefer alkaline water environment which forms on the carbonates that are very distributed in studied region. This environment gives us more chance to find new, unstudied aquatic objects in which can be revealed charophyte algae. The most important localities can be found in the mountain areas because altitude play the major role in historical species diversity forming process [1], especially it can be interesting in the Upper Jordan River basin, which placed in two different slopes of the Jordan Rift Valley [2, 3].

Geographically, Israel is partly situated in the eastern part of the Mediterranean region and partly within African-Eurasian Dry Zone [4]. Its territory contains several regions with diverse environmental features within its relative small area. Based on this environmental diversity, we can assume the great diversity of algae of continental water bodies of Israel and in particular charophytes. The history of the study of Israel charophytes has been recently described [5], and we continue finding of new existing localities of charophytes that hitherto not been detected. Close related regions, such as Turkey, also give us charophyte algae new localities that we studied in respect of species diversity and bio-indication of its environment $[6,7]$.

This paper is on a new locality of Chara, a rare and so far poorly studied genus of macrophytic algae in Israel. We assessed Chara habitat on the basis of complex study of algal diversity, indicator species and water chemistry. This approach can be useful for revealing anthropogenic stress in the protected area ecosystem.

\section{Materials and Methods}

\subsection{Sampling and Laboratory Studies}

Material for this study comes from seven living and six 
fixed algological samples, twelve samples of macroalgae and three samples of water that were collected during two field trips in May 2012 and August 2015 in the Sindyanna Natural Reserve ancient pool.

Algological samples were collected by scratching and scooping, placed in $15 \mathrm{ml}$ plastic tubes, and partly fixed with 3\% neutral formaldehyde solution, as well as partly not fixed and transported to the laboratory in the ice box.

We also used two dry samples of charophytes that were collected by Prof Yaakov Lipkin from this site in 17.08.1971 and up to now placed in the Tel Aviv University Herbarium (TELA) without description and publication.

The Chara samples were treated with $2-3 \% \mathrm{HCl}$ to remove calcium carbonate. After washing several times with distilled water the material was studied with Nikon stereomicroscope SMZ1000 with distilled water the material was air-dried on cover glasses and mounted in Naphrax resin. The structure elements were observed with Nikon stereomicroscope SMZ1000, Nikon Eclipse Ci-L with OMAX Digital Camera A35100U, DinoLight camera in the Institute of Evolution, University of Haifa and the Central Siberian Botanical Garden with help of international handbooks [8-9]. Charophyte and microscopic algae abundance were assessed as abundance scores according 6-score scale [10].

Algae and cyanobacteria were studied with the SWIFT and Nikon Eclipse Ci-L dissecting microscopes under magnifications $740 \mathrm{x}-1000 \mathrm{x}$ from three repetitions of each sample and were photographed with OMAX Digital Camera A35100U. The diatoms were prepared by the peroxide technique [11] modified for glass slides [12] and were placed in the Naphrax resin from two repetitions of each sample.

Algal species were identified in the Institute of Evolution, University of Haifa, and the Central Siberian Botanical Garden with help of international handbooks [8, 13-16].

Water temperature, acidity $(\mathrm{pH})$, conductivity (EC), and TDS were measured with HANNA HI 9813-0. This meter has a full-spectrum $\mathrm{pH}$ measurement range. The Electrical Conductivity range goes to $4.00 \mathrm{mS} \mathrm{cm} \mathrm{cm}^{-1}$. The TDS ranged from 0 to $1999 \mathrm{mg} \mathrm{l}^{-1}$. Measurements were made by adding the probe into the water till the reading was stabilized. The concentration of ${\mathrm{N}-\mathrm{NO}_{3}}_{3}$ was measured with HANNA HI 93728.

Water Quality Class system including species-indicators ecological preferences was used according Sládeček [17] where the best Class is I, and poor water quality is Class V.

Index saprobity s was calculated according to [18]. Index of aquatic ecosystem sustainable was calculated according to $[10,19]$ as $(1)$ :

$$
\text { WESI }=\text { Rank S / Rank }{\mathrm{N}-\mathrm{NO}_{3}}_{2}
$$

Where: Rank S - rank of water quality on the Sladeček's indices of saprobity; Rank $\mathrm{N}^{-\mathrm{NO}_{3}}$ - rank of water quality on the nitric-nitrogen concentration (Table 1).

If WESI is equal to or larger than 1, the photosynthetic level is positively correlated with the level of nitrate concentration. If the WESI is less than 1, the photosynthesis is suppressed presumably according to toxic disturbance [10].

\subsection{Description of the Study Site}

The Sindyanna ancient pool is situated in the Sindyanna Natural Reserve in the upper part of the Jordan River Basin on the Golan Heights (Figure 1).The locality altitude is about $710 \mathrm{~m}$ above sea level with coordinates $33^{\circ} 02^{\prime} 758 \mathrm{~N}$, $35^{\circ} 45^{\prime} 320 \mathrm{E}$ on the eastern slope of the rift valley near the Katsrin settlement. The pool is about $70-50 \mathrm{~m}$ in diameter and up to one $\mathrm{m}$ deep, placed in topographic depression on basalt (Figure 2), filled by natural rainy waters during winter. Pool is natural, long-term, which is also a nature reserve, which is a habitat for plants from water as well as animals, such as amphibians, many. The pool is wonderful and animals attracted to it. In winter are visitors here coots and ducks. The pool is watered full even at the height of summer [20]. Pool is located on a ruderal west faced hillside of the Golan Heights as a part of ancient protected historical site, and used for recreation year-round, but mostly in summer. Climatic condition of the Sindyanna area is warm and temperate. The rain falls mostly in the winter, with relatively little rain in the summer. The average annual temperature is $19.5^{\circ} \mathrm{C}$. The average annual rainfall is 511 $\mathrm{mm}$. The driest month is June, with $0 \mathrm{~mm}$ of rain. In January, the precipitation reaches its peak with an average of $134 \mathrm{~mm}$. August is the warmest month of the year. The temperature in August averages $27.3{ }^{\circ} \mathrm{C}$. On average, January is the coldest month of the year with $11.1^{\circ} \mathrm{C}$ [21]. There is a difference of $134 \mathrm{~mm}$ of precipitation between the driest and wettest months. The variation in annual temperature is around $16.2^{\circ} \mathrm{C}$.

Annual mean solar radiations rate in the pool area is rather high, about 182-189 kg-calories $\mathrm{cm}^{2}$ year ${ }^{-1}$ [22], like in the Judean Mountain and even in the upper Negev Desert. Therefore environment is very favorable for the development of photosynthetic plants, and charophyte algae which are truly photosynthetic organisms. 


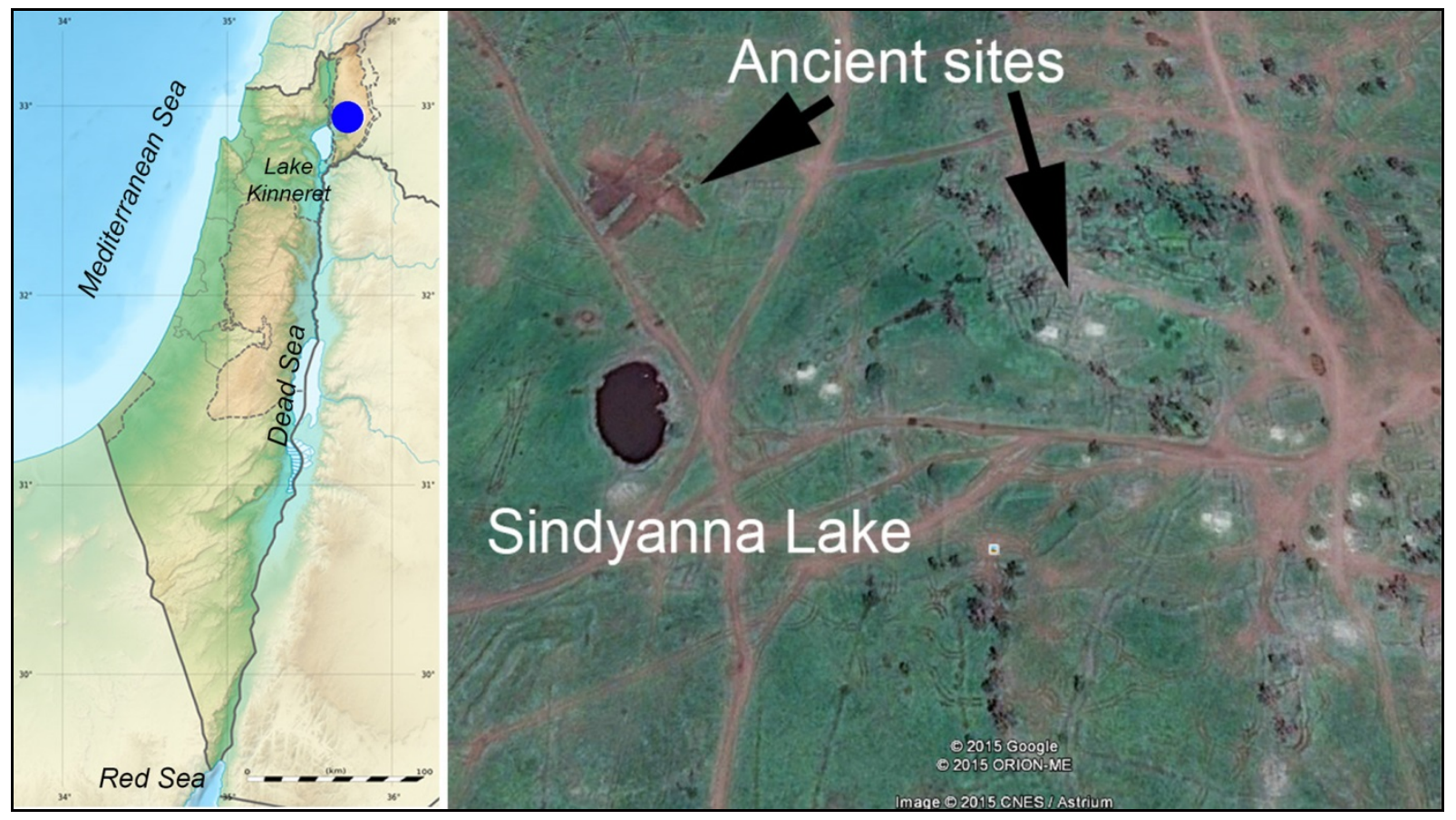

Figure 1. The Sindyanna pool (blue circle) in the ancient site locality in the Upper Jordan Basin, Northern Israel

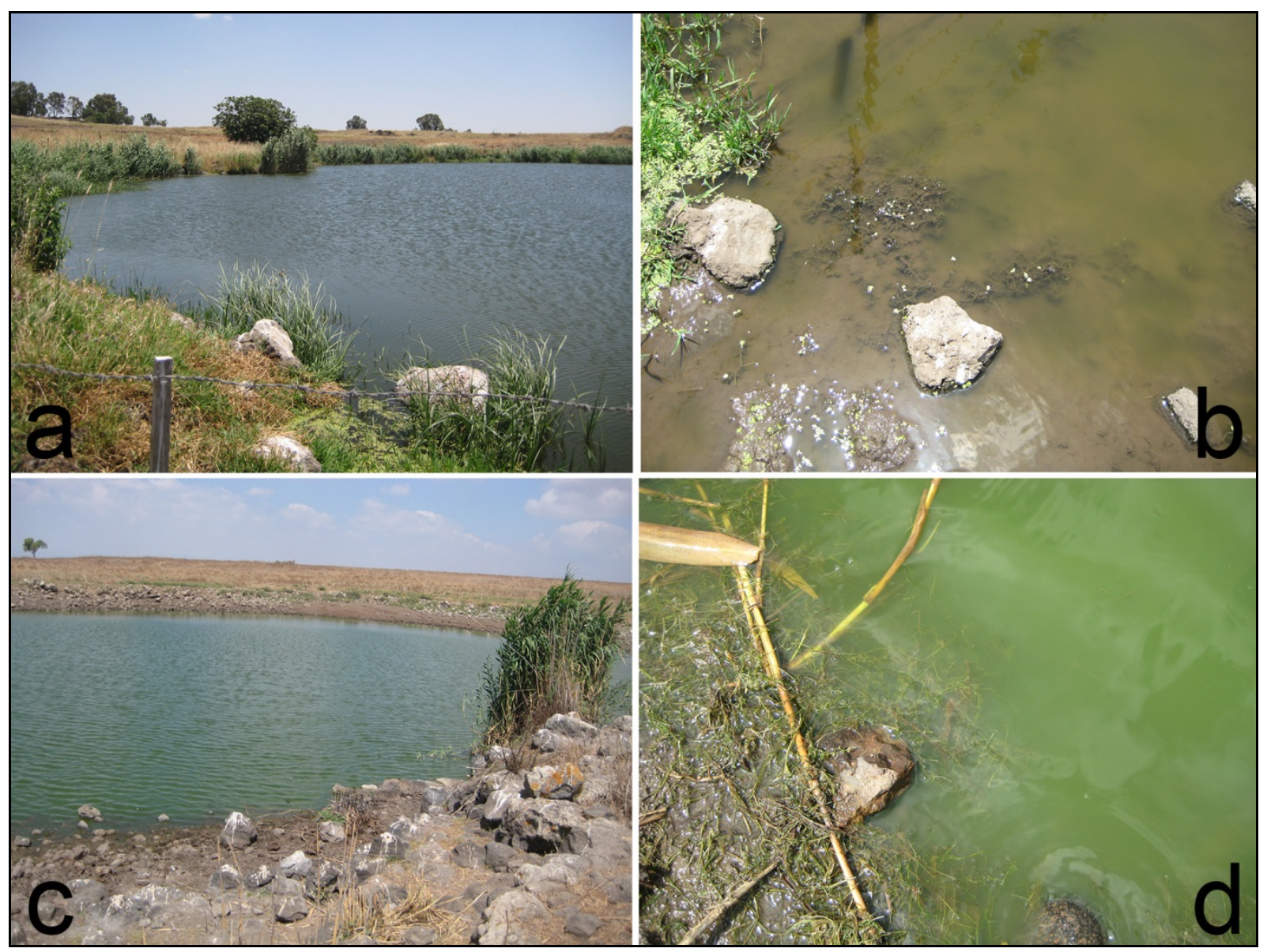

Figure 2. The Sindyanna pool in the Northern Israel: a - view of locality in the wetted season of 2012, b - Chara globularis plants on the bank of pool, c - view of pool in dry period of 2015, d - Chara globularis massive grows in 2015. 


\section{Results and Discussion}

\subsection{Chemical Composition of the Pool Water}

Chemical variables were measured in two seasons: at the end of summer and at the end of winter. Table 1 show that environmental variables are fluctuated in small range (excluding high nitrates concentration and high $\mathrm{pH}$ in summer) and reflected fresh, low alkaline, temperate temperature, and middle to low polluted waters [10, 19]. Index of saprobity $\mathrm{S}$ is fluctuated between 1.74 in winter and 1.99 in summer, reflect Class III of Water Quality that is slightly decrease during the dry period.

Table 1. Averaged chemical and biological variables of the Syndianna pool in 2012-2015

\begin{tabular}{|c|c|c|}
\hline \multirow{2}{*}{ Variables } & Winter & Summer \\
\hline & May 2012 & August 2015 \\
\hline Conductivity, $\mathrm{mS} \mathrm{cm}^{-1}$ & 0.375 & 0.530 \\
\hline $\mathrm{N}-\mathrm{NO}_{3}, \mathrm{mg} \mathrm{l}^{-1}$ & 0.40 & 8.16 \\
\hline $\mathrm{pH}$ & 8.4 & 10.0 \\
\hline Total Dissolved Solids (TDS), $\mathrm{mg}^{1^{-1}}$ & 268.5 & 384.0 \\
\hline Temperature & 24.75 & 26.2 \\
\hline $\mathrm{Cl}^{-g} 1^{-1}$ & About 0 & About 0 \\
\hline Index saprobity $\mathrm{S}$ & 1.74 & 1.99 \\
\hline WESI & 3 & 0.44 \\
\hline No. of Species & 33 & 24 \\
\hline
\end{tabular}

\subsection{Diversity and Ecology of Algae}

Altogether we revealed fifty four species of algae (Table 2) diversity of which is rather is slightly decreased during the dry period. Studied pool banks were covered by macrophyte alga Chara globularis (Figure 3), which was more abundant in summer (Figure 2). Structural elements and thallus habitat show (Figure 3), that our samples are in the typical diagnosis frames. It is also widely distributed species in the Mediterranean countries and some climatic similar dry regions [23]. It is a cosmopolitan species but most of records are known from Northern Hemisphere [9]. Chara globularis was referred to generalist in northern, central and western Europe [24-26]. It is one of the most tolerant to eutrophication species able to grow even in hypertrophic water reservoirs. No other macrophytic or filamentous algae dominated in pool.

Algal community content is rather changed between rainy and dry seasons (Figure 5). Table 2 and Figure 5 show that species richness was decreased in the summer community with increasing green algae species number in the same time. Species abundance was changed with cyanobacteria Dolichospermum spiroides dominating community in the dry period, whereas chlorophytes like Actinastrum hantzschii were abundant in the rainy period. Remarkable that avoid the Chara, both abundant species are planktonic (Table 2), which confirm that pool is permanent and stay here long time.

Massive Chara growth is correlated with organic enrichments of the water during dry period that can give large nutrient base for charophytes development. Chara globularis was reported for several water bodies in Israel [27] but now this species has a limited distribution in Israel because habitats in Coastal Plane were lost under anthropogenic impact [5]. As a result, only two recent localities are known, including Sindyanna inhabited by $C$. globularis in the Mediterranean climatic zone [28] of Israel. Other fifty three identified species in the Sindyanna locality were from six taxonomic Divisions, and represents mostly by diatoms attached to macrophytes, plants, and stones in the pool.

We are recognized in the Tel Aviv Herbarium (TELA) few samples of charophytes collected by Dr Yaakov Lipkin in August 1971 from the Sindyanna pool. Studies of species morphology in these two samples let us to conclude that forty four years ago the Sindyanna pool was inhabit by Chara connivens P. Salzmann ex A. Braun. This species is simply distinguished from similar $C$. globularis in the field because have male and female plants in the same population (Figure 4). Few localities with $C$. connivens were found in Coastal Plain of Israel and Hula Valley but now they lost as a result of anthropogenic transformation of the territory [5]. Therefore, $C$. connivens can be access as sensitive species which have no chance to survive in disturbed and polluted areas. In the Sindyanna Natural Reserve this species now is replaced by another species of charophyte algae $-C$. globularis, possibly as a result of the succession under anthropogenic impact. Both Chara species were found to be tolerant to nutrient enrichment in Western Mediterranean and western Europe [26,29,30]. 


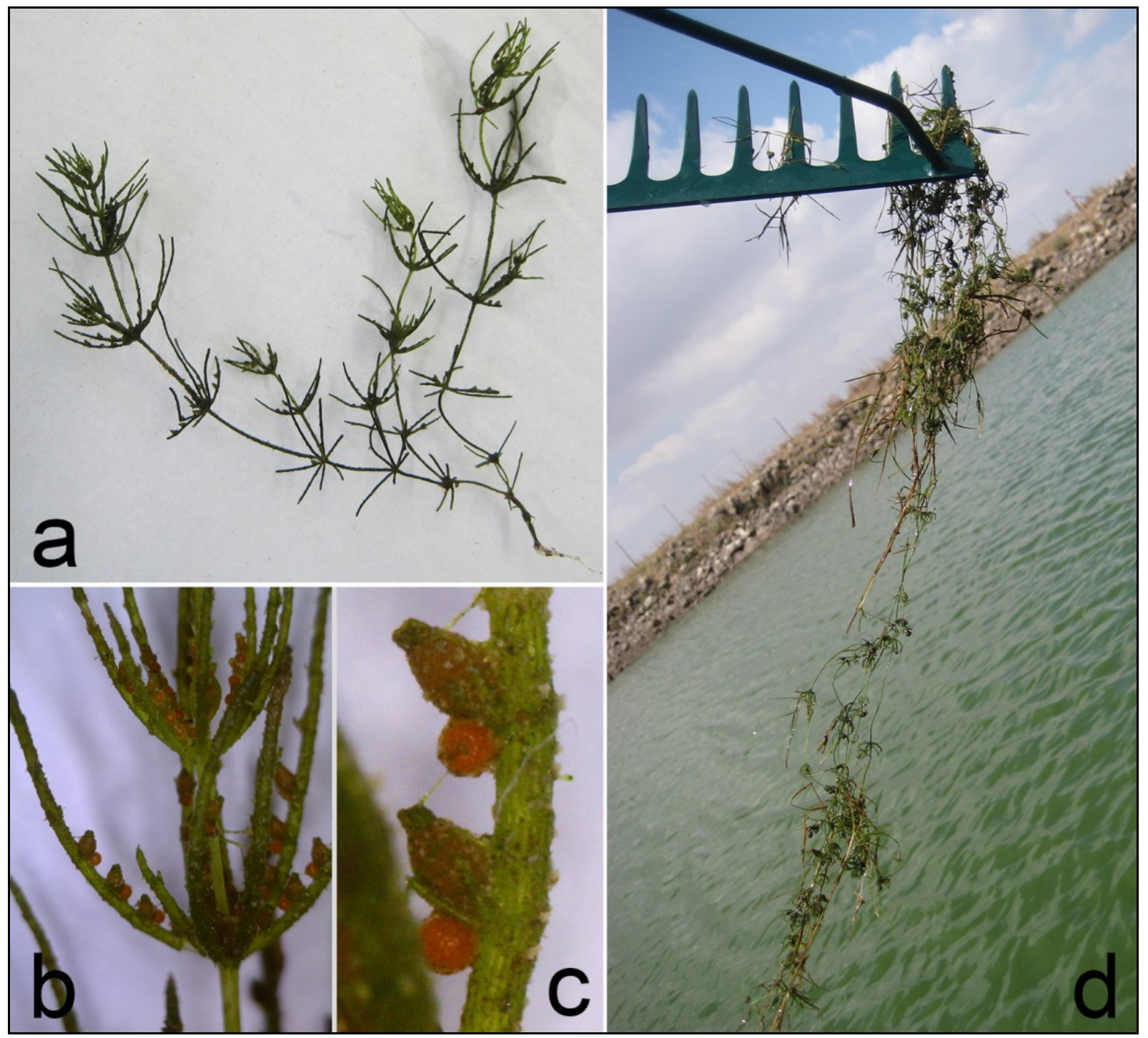

Figure 3. Chara globularis: $\mathrm{a}$ - view of thallus, $\mathrm{b}$ - upper part of thallus, $\mathrm{c}-$ conjoned gametangia on the branchlet, $\mathrm{d}-$ Chara sampling in the Sindyanna pool in 2015. 


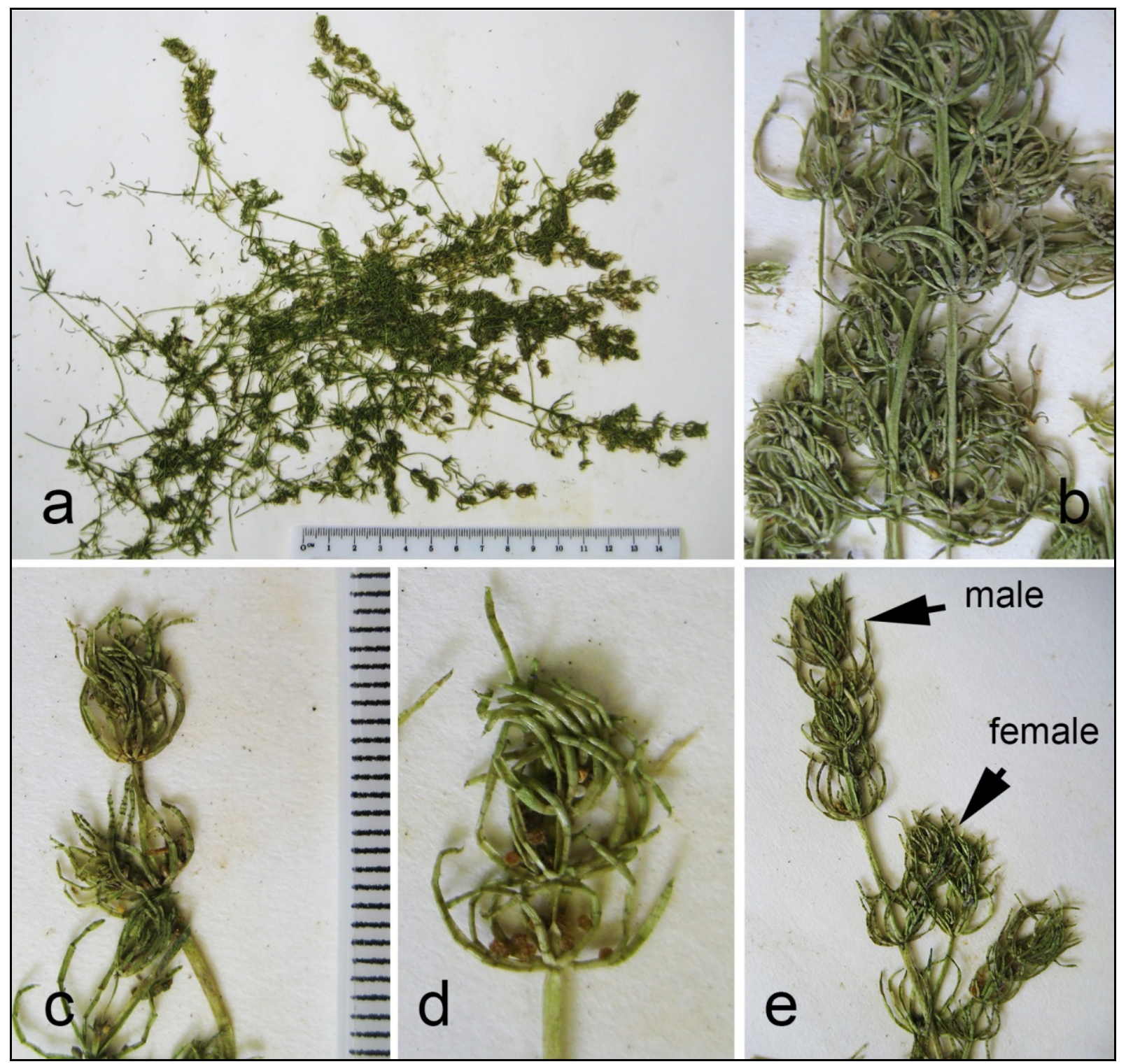

Figure 4. Chara connivens from Prof Yaakov Lipkin collection (TELA): a - view of thallus, $\mathrm{b}-$ details of plants, $\mathrm{c}-$ female thallus, $\mathrm{d}-$ mail thallus, $\mathrm{e}-$ joint presence of male and female plants in Sindyanna pool in 1971.

\subsection{Bio-indication of the Sindyanna Pool Environment}

We use bio-indication methods in purpose to characterize of the pool water quality and ecosystem sustainable. As can be seen in Table 2, the water quality defined by bio-indication is the same that show by water chemistry (Table 1). In addition we can characterize pool as eutrophic with prevailing of organisms with autotrophic type of nutrition, which are mostly attached of substrate.

We use Table 2 with Index saprobity $S$ value that we calculated on the base of species abundance scores and species-specific index s (after Sládeček [17] model) and nitrate concentration data (Table 1) for ecosystem state index WESI calculation. Thus, winter WESI is 3.0 , while summer WESI is 0.44 . Can be seen that ecosystem was in good condition during winter rainy season than in summer when was impacted by the organic enrichments come from the catchment area mostly from livestock. This situation is contrary to that of the Upper Jordan River previously examined by us [3] where the pollution coming from the catchment area pollute the water more in winter than in summer. It can be related with decreasing of water volume in dry period with the same livestock grazing press. Figure 6 show that species richness decreased with the Index WESI decreasing when Index Saprobity S increased. It can be interpreted as a result of toxic instances stress for algal community that comes together with organic pollution from the basin area. 


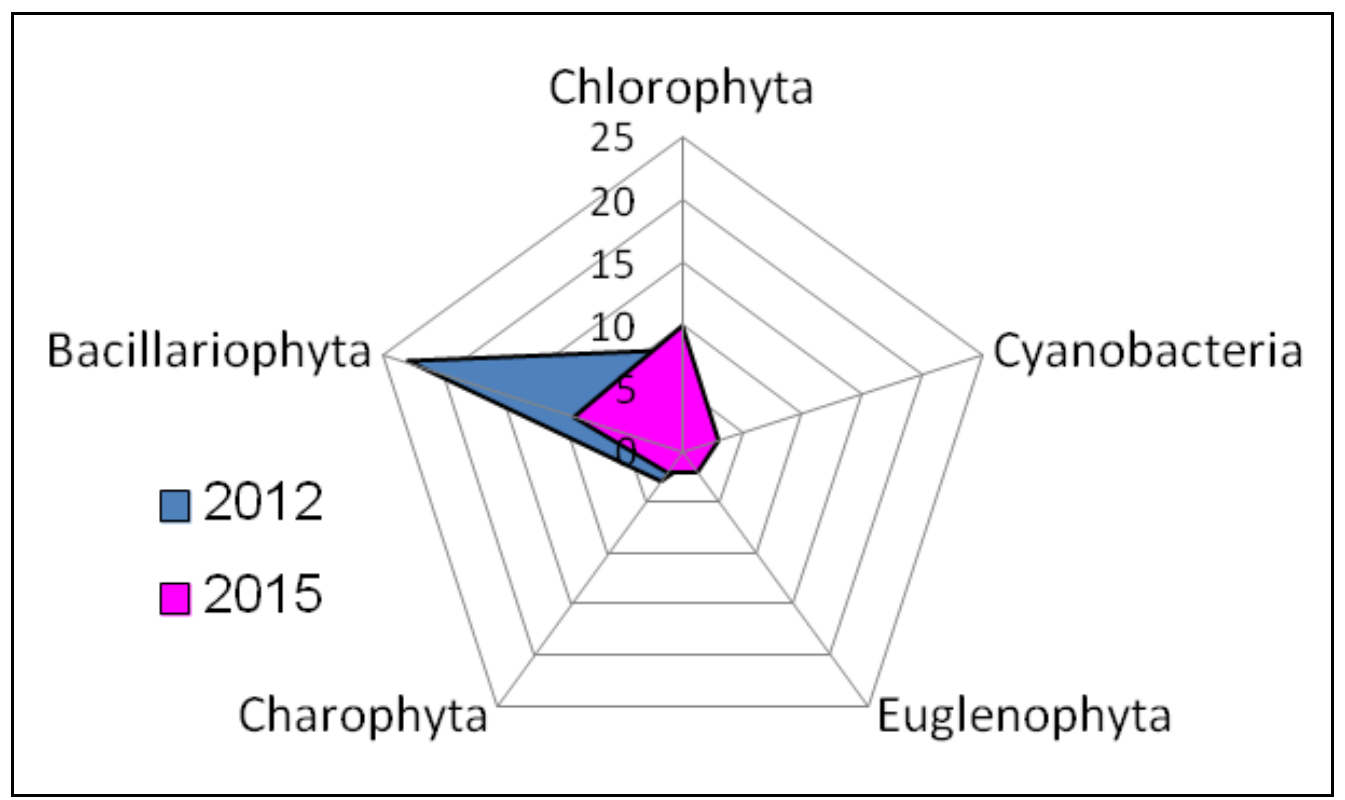

Figure 5. Distribution of algal species over taxonomic Division in the Sindyanna pool communities during wet (2012) and dry (2015) periods.

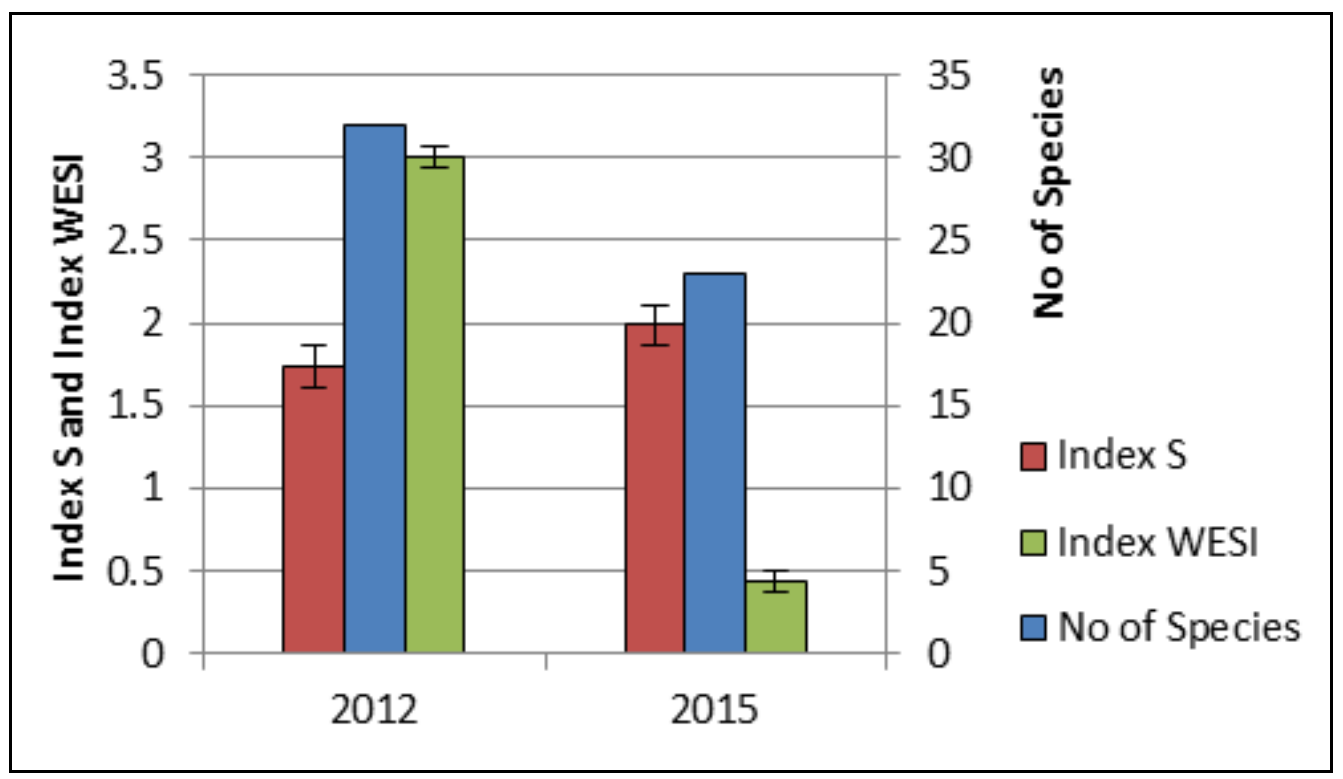

Figure 6. Dynamic of Index Saprobity S, Index WESI and algal species richness of the Sindyanna pool community in 2012 (wet) and 2015 (dry) seasons. Error bar is Standard Deviation for data.

We analyzed distribution of Water Quality indicators over Classes during wet and dry periods. Figure 7 show that wet season community of 2012 is mostly represented by clear-water species of Class I-III, whereas summer community of 2015 is enriched by species of Class III and V with absent of species Class I. 


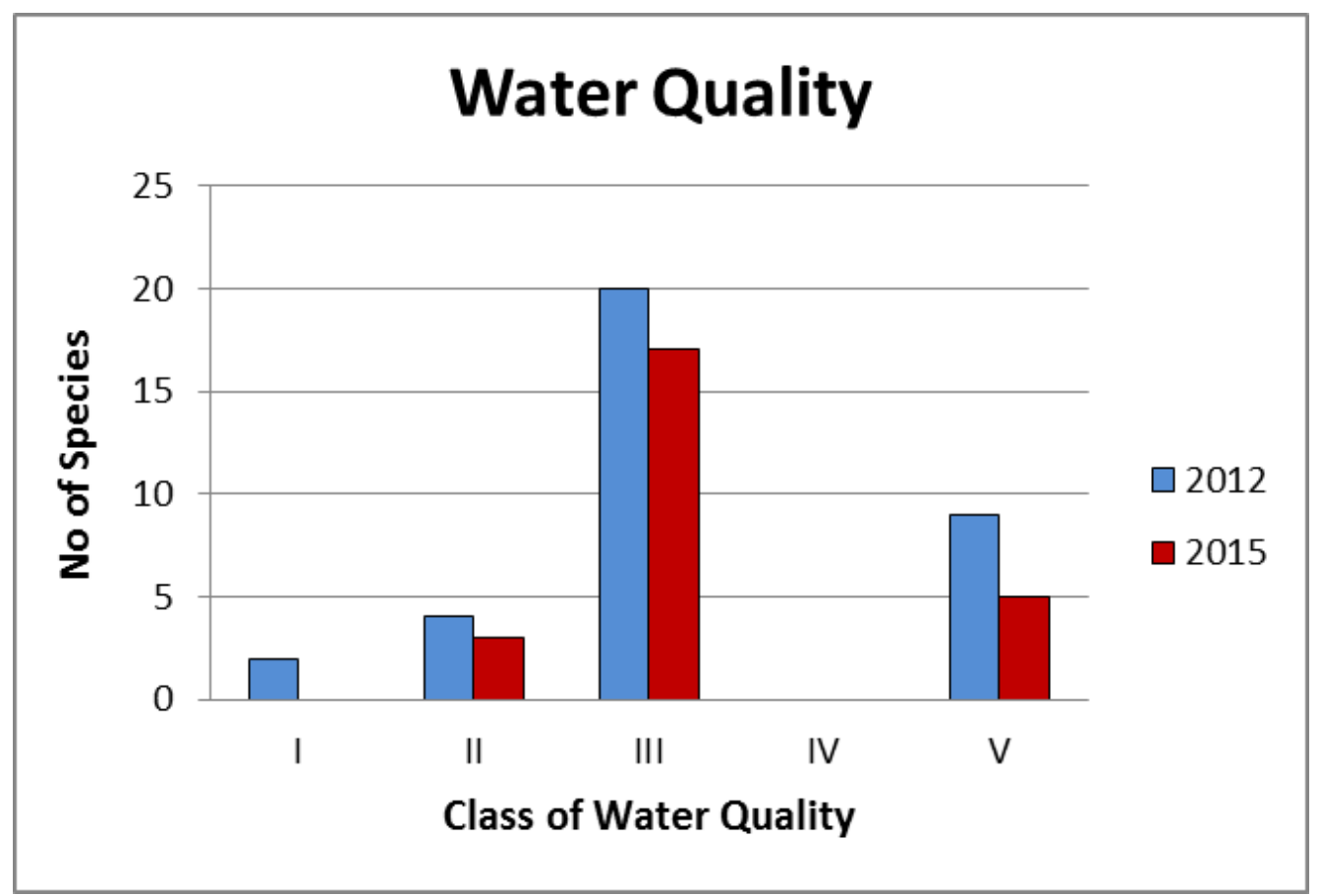

Figure 7. Distribution of species-indicators over Water Quality Classes in the Sindyanna pool during wet (2012) and dry (2015) periods 


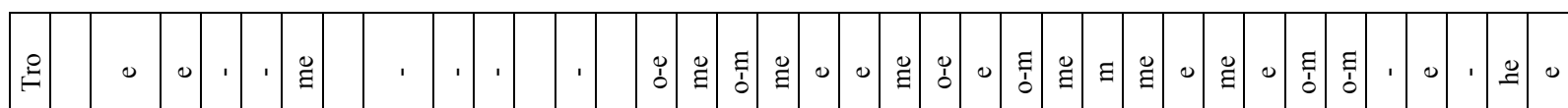

离

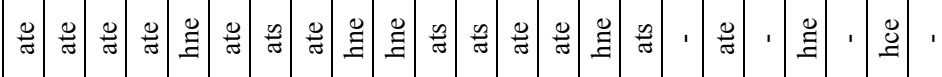

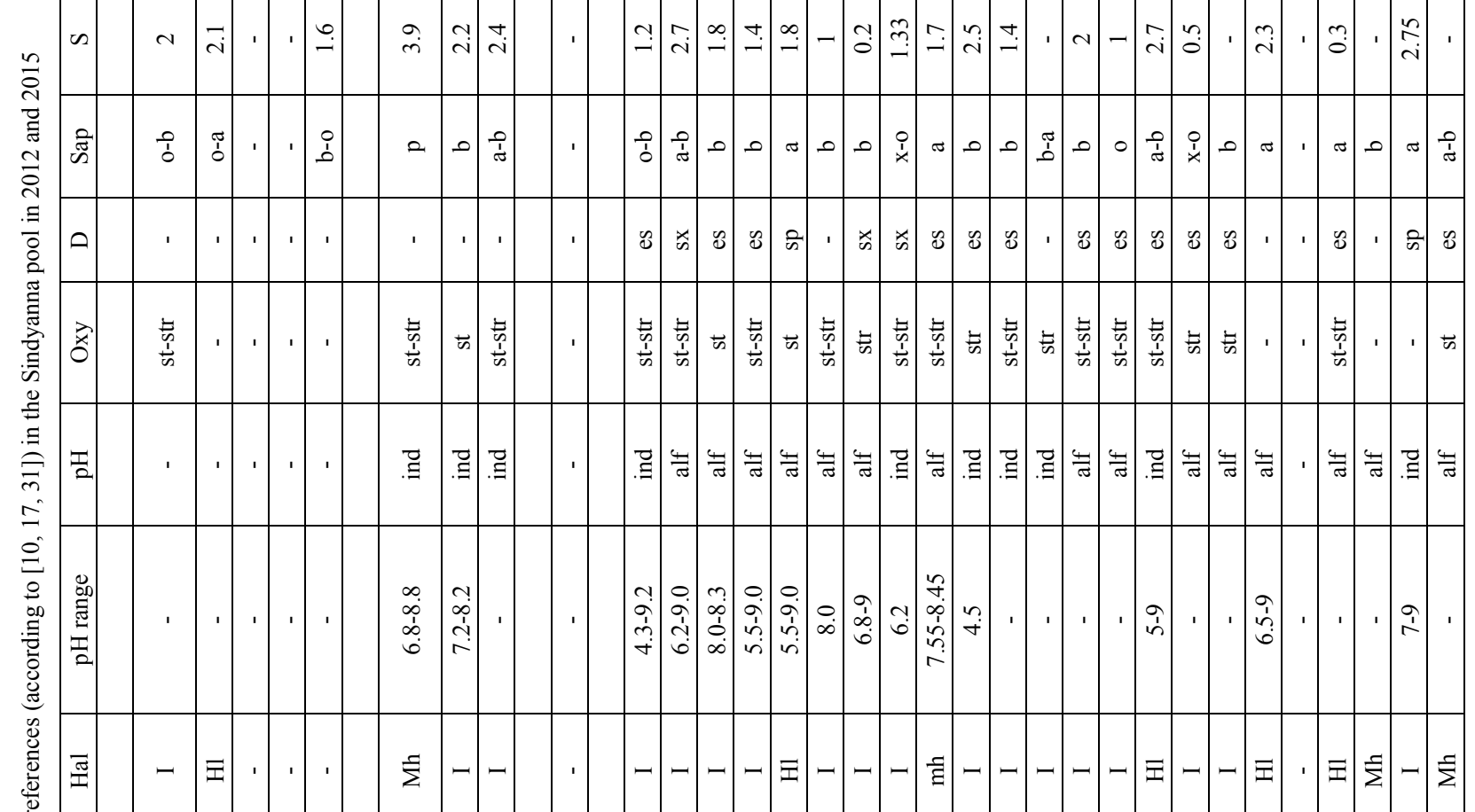

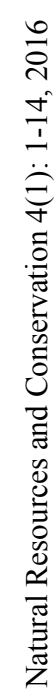

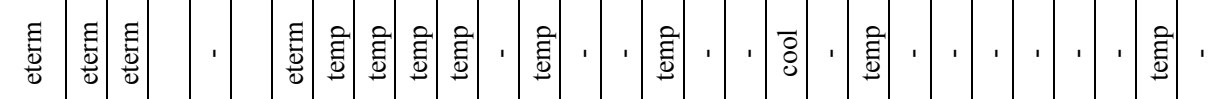

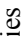

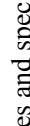

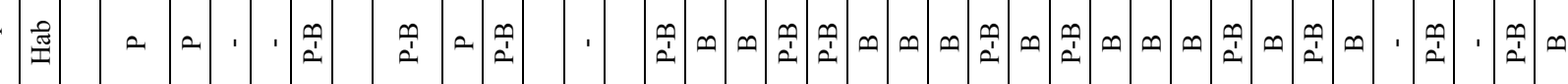

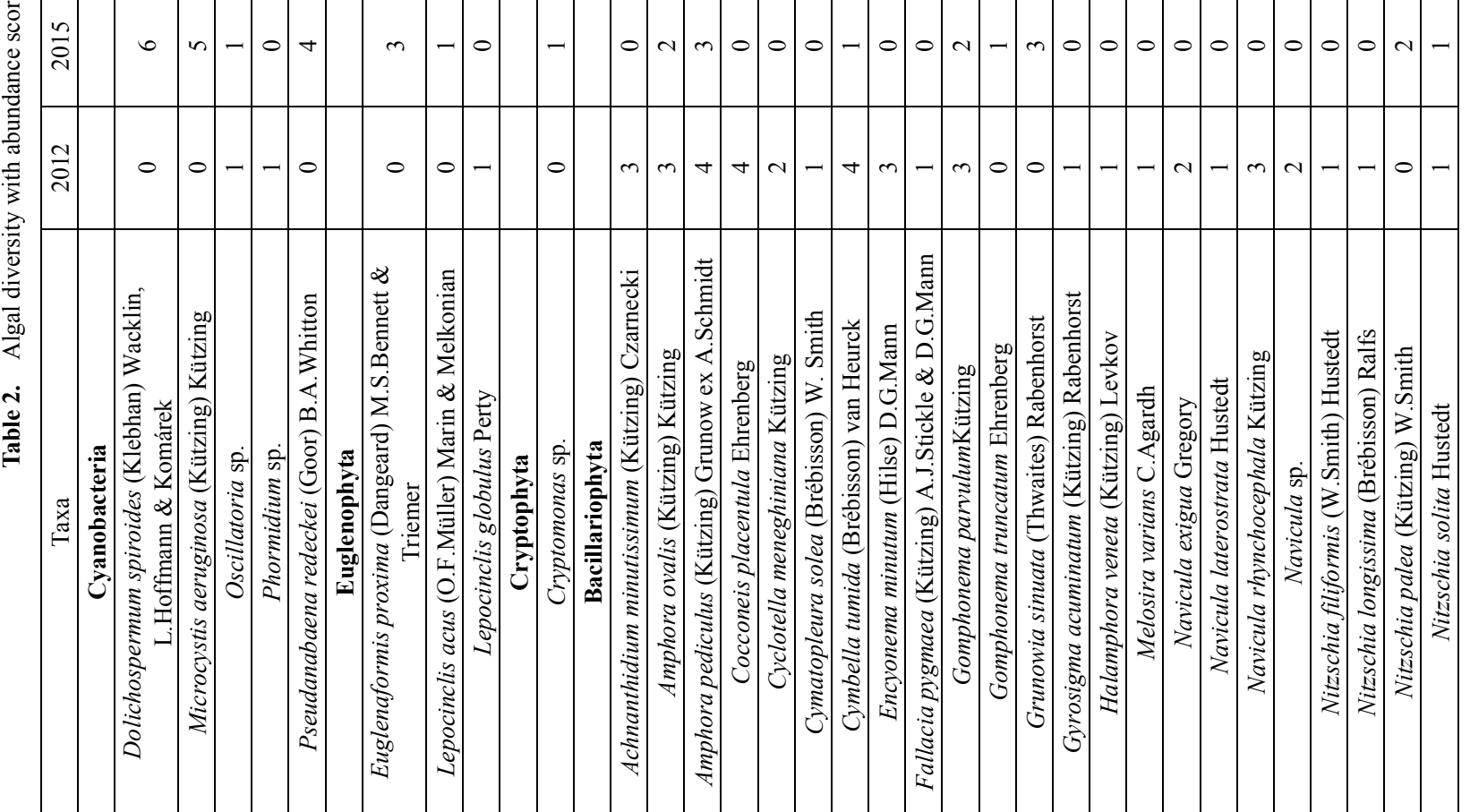




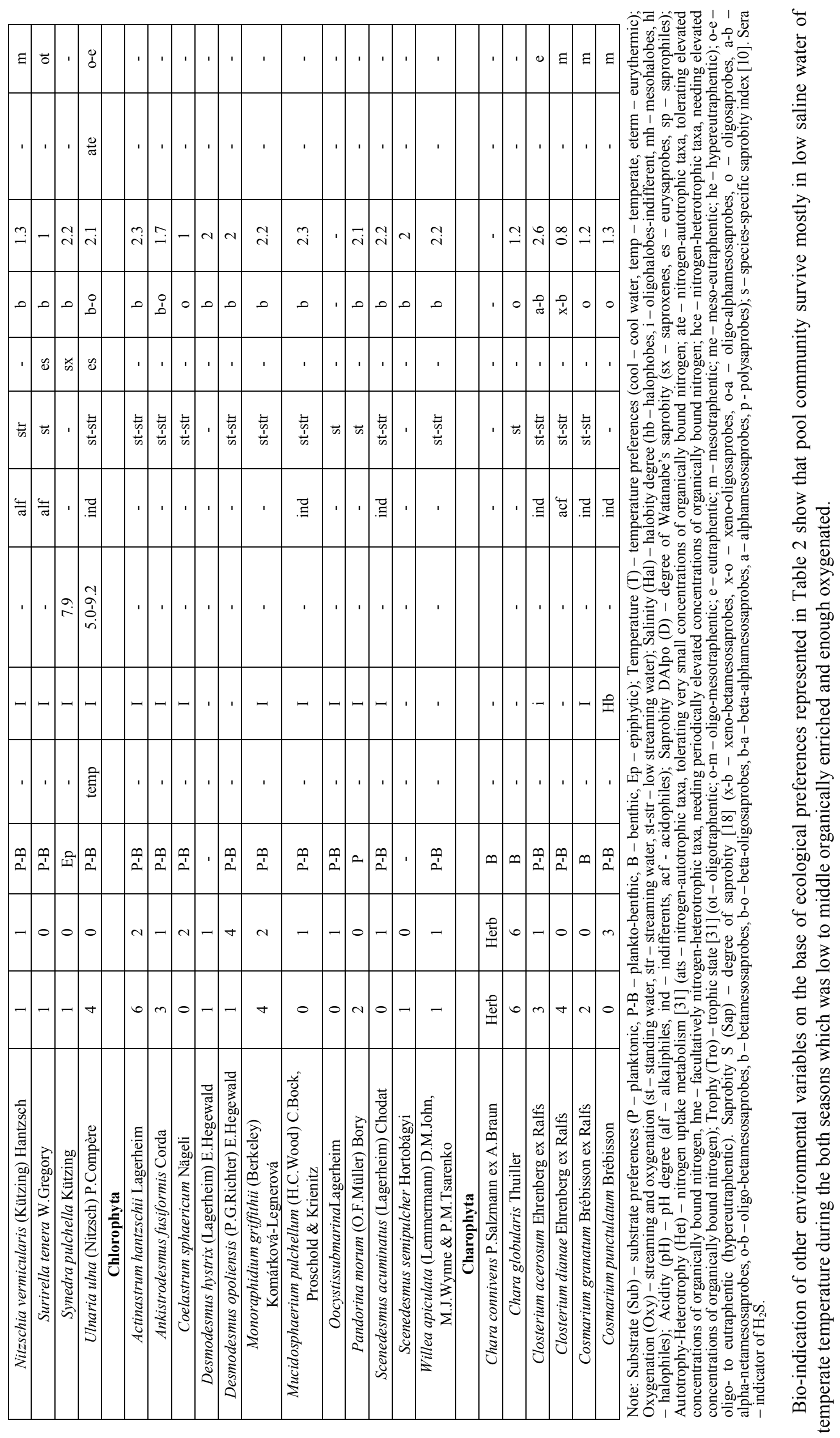




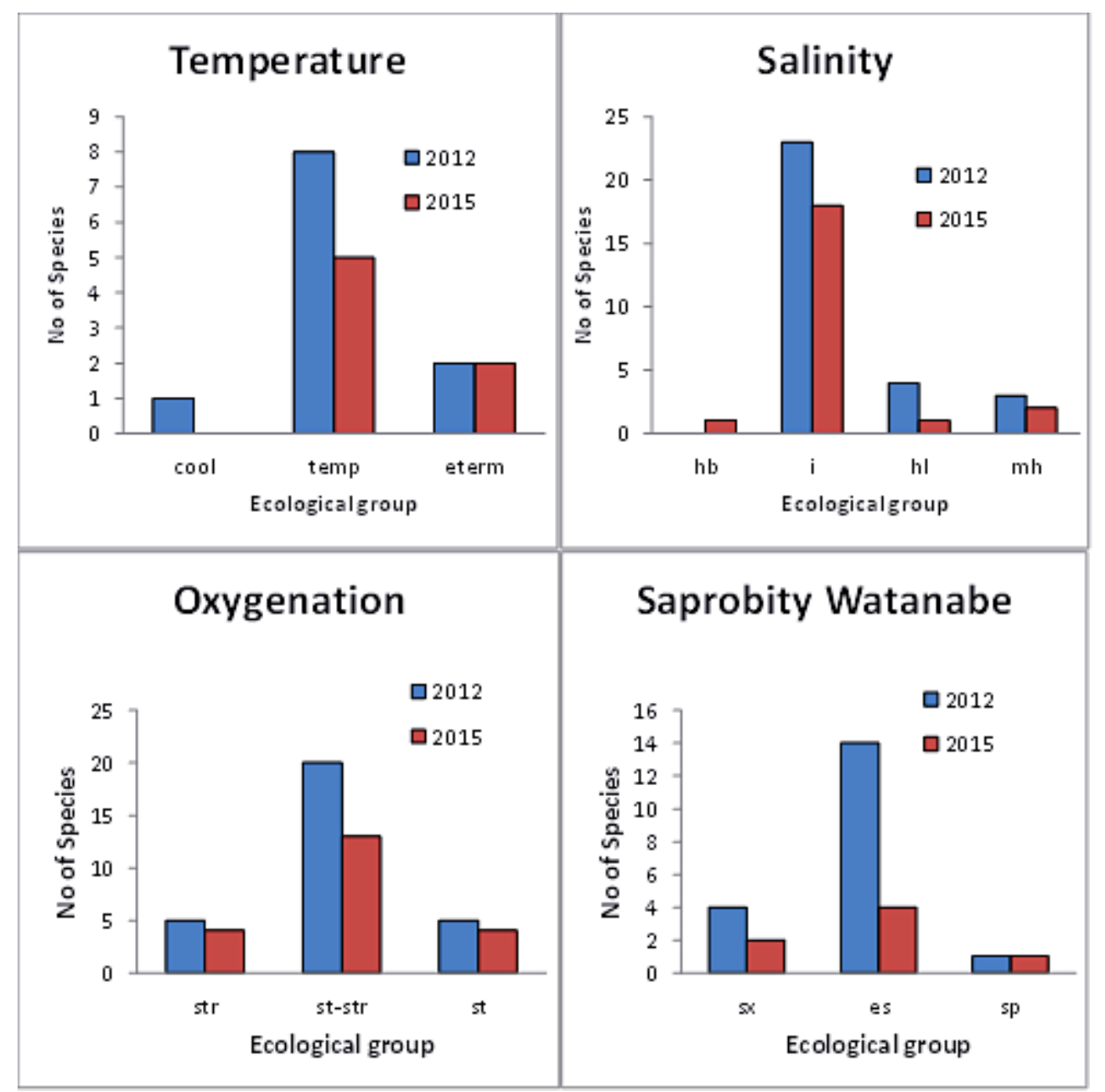

Figure 8. Distribution of algal indicators of temperature, salinity, oxygenation, and saprobity (according Watanabe) over ecological groups in the Sindyanna pool during wet (2012) and dry (2015) periods. 


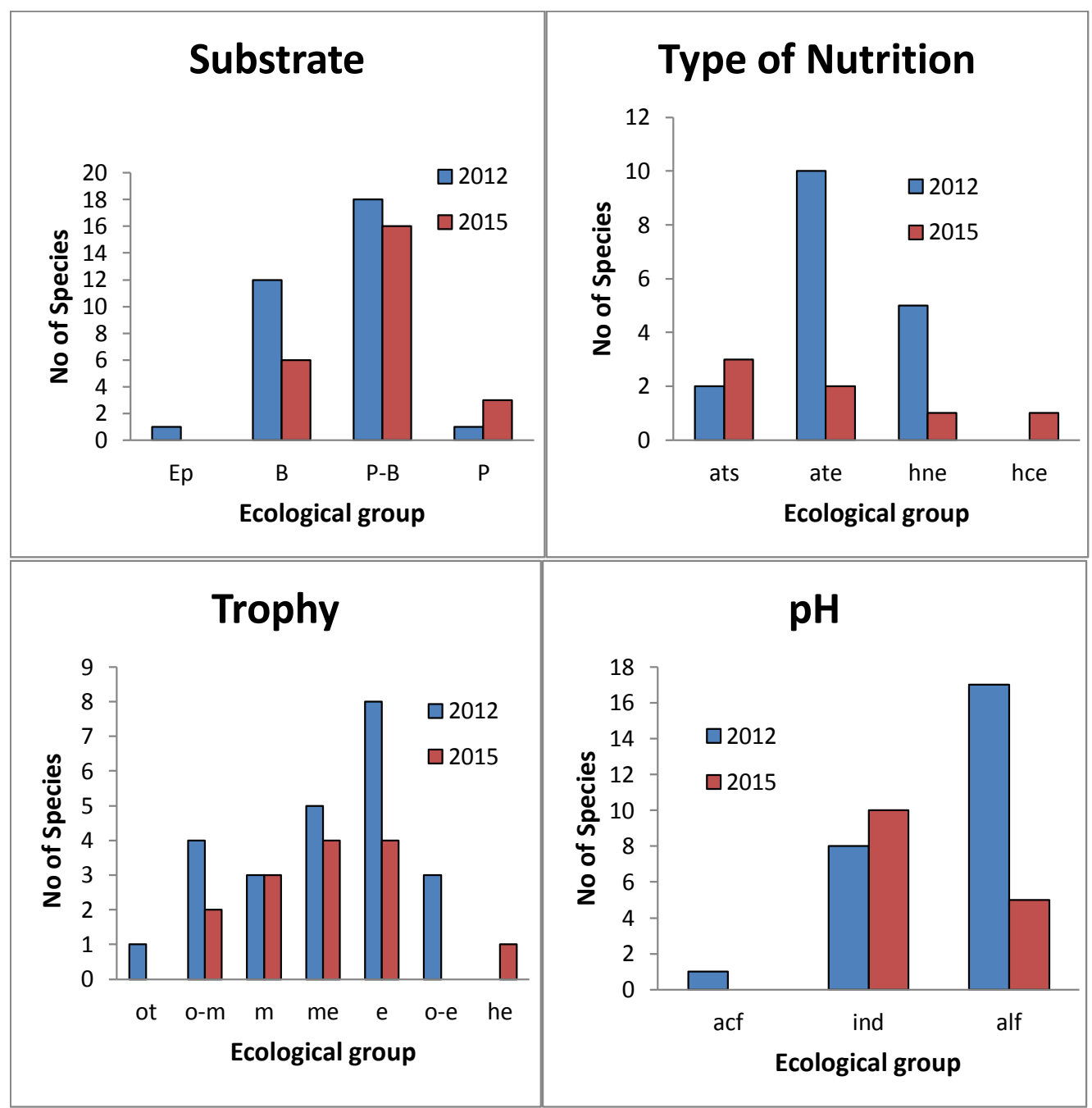

Figure 9. Distribution of algal indicators of substrate preferences, type of nutrition, trophic state, and water pH over ecological groups in the Sindyanna pool during wet (2012) and dry (2015) periods.

Distribution of substrate preferences indicators is similar in wet and dry periods (Figure 9). But nutrition type indicators were changed from prevailing of autotropic type in the winter community to increasing of facultative heterotrophes in dry period. Trophic level indicators show (Figure 9) that Sindyanna pool ecosystem was mostly mesotrophic in winter and eutrophic in summer. Indicator $\mathrm{H}_{2} \mathrm{~S}$ - Pseudanabaena redeckei was found in summer community and reflects anaerobic processes in the bottom of the studied pool in hot and organically enriched water. With anoxia and organic enrichments was correlated extremely high water $\mathrm{pH}$ - up to 10.0 .

As a whole, bio-indication results and calculated indices show high capacity of the Sindyanna pool ecosystem to self-purification.

\section{Conclusions}

Charophytes study in Israel is in initial stage. The ancient pool in the Sindyanna Natural Reserve was new studied locality in protected area of the Upper Jordan River Basin on the Golan Heights can be characterize as natural, fresh, low alkaline with middle organic polluted waters that inhabit by fifty four algal species from which the charophytes Chara globularis (Characeae). Chara community was enriched by planktonic green algae Actinastrum hantzschii in winter season, whereas in summer planktonic cyanobacteria Dolichospermum spiroides was rather dominated with decreasing of total species number. Historical finds of Chara connivens can be marked as sensitive species to anthropogenic stress. This species now are replaced with $C$. globularis. In any case the Sindyanna pool is ancient locality with only one population of $C$. globularis in Israel in present time.

The Sindyanna pool ecosystem is impacted by livestock mostly in summer and as a result of it algal community was enriched by indicator species of anoxia in dry period. Anoxia, high water $\mathrm{pH}$, increasing of nitrates enrichments in dry period together with decreasing of index WESI which can reflect some of toxicity impact, that all can be results of livestock grazing in the pool catchment area. The quality of pool water assessed with help of bio-indication as fresh, low- to high alkaline, low to temperate temperature, 
with low- to middle polluted waters that enough saturated by oxygen. Index of saprobity $\mathrm{S}$ was fluctuated between 1.74 and 1.99, reflect Class III of Water Quality. Therefore, the new Chara locality in protected area of the Upper Jordan River Basin can be monitored with using of chemical and bio-indication methods in purpose to save of aquatic ecosystem health if historically important ancient locality. The Sindyanna pool must be protected from excessive livestock grazing, as well as represented more visual information for visitors.

\section{Acknowledgements}

We thank Michel Margulis for her assistance in the field trip, Marcelo Sternberg for the possibility to study of herbarium specimens (TELA). This work was partly funded by the Israeli Ministry of Absorption, Israel Taxonomy Initiative and Russian Foundation for Basic Research, project 16-04-00931-a.

\section{REFERENCES}

[1] S. Barinova. The effect of altitude on distribution of freshwater algae in continental Israel, Current Topics in Plant Biology, Vol.12, 89-95, 2011a.

[2] A. Horowitz. The Jordan Rift Valley, A.A. Balkema Publishers, Lisse, Exton, PA, 2001.

[3] S.S. Barinova, E. Nevo. The Upper Jordan River algal communities are evidence of long-term climatic and anthropogenic impacts, J. Water Resource and Protection, Vol.2, 507-526, 2010.

[4] A.S. Perry, R.Y. Perry. Effects in arid regions. In: Ecotoxicology and Climate, SCOPE, Published by John Wiley and Sons Ltd., 1989.

[5] R. E. Romanov, S. S. Barinova. The charophytes of Israel: historical and contemporary species richness, distribution, and ecology, Biodiv. Res. Conserv., Vol.25, 57-64, 2012.

[6] S. Barinova, C.N. Solak, O. Erdoğan, R. Romanov. Algae and Zooplankton in Ecological Assessment of the Işıklı Lake, Turkey, Aquatic Biology Research, Vol.2, No.2, 23-35, $2014 \mathrm{a}$.

[7] S. Barinova, R. Romanov, C.N. Solak. New record of Chara hispida (L.) Hartm. (Streptophyta: Charophyceae, Charales) from the Işıklı Lake (Turkey) and critical checklist of Turkish charophytes, Natural Resources and Conservation, Vol.2, No.3, 33-42, 2014b.

[8] D. M. John, B. A. Whitton, A. J. Brook (Eds.). The freshwater algal flora of the British Isles: an identification guide to freshwater and terrestrial algae, Cambridge University Press, Cambridge, 2011.

[9] W. Krause. Charales (Charophyceae). Süßwasserflora von Mitteleuropa, Vol.18, Gustav Fischer Verlag, Stuttgart, 1997.

[10] S. S. Barinova, L. A. Medvedeva, O.V. Anissimova.
Diversity of algal indicators in environmental assessment. Pilies Studio, Tel Aviv, (Book in Russian with tables and annotation in English), 2006.

[11] E. Swift. Cleaning Diatom Frustules with Ultraviolet Radiation and Peroxide, Phycologia, Vol.6, No.2-3, 161-163, 1967.

[12] S. S. Barinova. Morphology of connective spines in diatom algae of the genus Aulacoseira Thwaites, Paleontological Journal, Vol.31, No.2, 239-245, 1997.

[13] G. Hofmann, M. Werum, H. Lange-Bertalot. Diatomeen im Süßwasser-Benthos von Mitteleuropa, A.R.G. Gantner Verlag K.G., Ruggell, 2011.

[14] K. Krammer, H. Lange-Bertalot. Bacillariophyceae 1. Teil: Naviculaceae. Süßwasserflora von Mitteleuropa, 2(1), G. Fischer Verlag, Stuttgart, New York, 1986.

[15] K. Krammer, H. Lange-Bertalot. Bacillariophyceae 2. Teil: Bacillariaceae, Epithemiaceae, Surirellaceae. Süßwasserflora von Mitteleuropa, 2(2), G. Fischer Verlag, Stuttgart, New York, 1988.

[16] K. Krammer, H. Lange-Bertalot. Bacillariophyceae 4. Teil: Achnanthaceae. Kritische Erganzungen zu Navicula (Lineolatae) und Gomphonema, Gesamtliteraturverzeichnis. Süßwasserflora von Mitteleuropa, 2(4), G. Fischer Verlag, Stuttgart, New York, 1991.

[17] V. Sládeček. System of water quality from the biological point of view, Ergebnisse der Limnologie, Vol.7, 1-128, 1973.

[18] V. Sládeček. Diatoms as indicators of organic pollution, Acta Hydroch. Hydrob., Vol.14, 555-566, 1986.

[19] S. Barinova. Algal diversity dynamics, ecological assessment, and monitoring in the river ecosystems of the eastern Mediterranean, Nova Science Publishers, New York, USA, $2011 b$.

[20] http://amudanan.co.il/.

[21] http://en.climate-data.org/location/59499.

[22] D. H. K. Amiram, N. Rosenan, N. Kadmon, J. Elster, M. Gilead, U. Paran (Eds.). Atlas of Israel, Ministry of Labour, Jerusalem, and Elsevier Publishing Co., Amsterdam, 1970.

[23] algaebase.org.

[24] L. Baastrup-Spohr, L. L. Iversen, J. Borum, K. Sand-Jensen. Niche specialization and functional traits regulate the rarity of charophytes in the Nordic countries. Aquatic Conservation: Marine and Freshwater Ecosystems, Vol. 25, No. 5, 609-621, 2015. DOI: $10.1002 /$ aqc. 2544.

[25] A. Rey-Boissezon, D. Auderset Joye. Habitat requirements of charophytes - Evidence of species discrimination through distribution analysis, Aquatic Botany, Vol. 120, 84-91, 2015. DOI:10.1016/j.aquabot.2014.05.007.

[26] E. Lambert-Servien, G. Clemenceau, O. Gabory, E. Douillard, J. Haury. Stoneworts (Characeae) and associated macrophyte species as indicators of water quality and human activities in the Pays-de-la-Loire region, France, Hydrobiologia, Vol. 570, 107-115, 2006. DOI: 10.1007/978-1-4020-5390-0 16.

[27] V. W. Proctor. Chara globularis Thuillier (= C. fragilis Desvaux): breeding patterns within a cosmopolitan complex, Limnology and Oceanography, Vol. 16, 422-436, 1971. 
[28] M. Galun. The Lichens of Israel, The Israel Academy of Sciences and Humanities, Jerusalem, 1970.

[29] R. del Pozo, C. Fernández-Aláez, M. Fernández-Aláez, N.-F. Santiago. Assessment of eutrophication effects on charophytes in Mediterranean ponds (North-Western Spain). Fundam. Appl. Limnol., Vol. 178/3, 257-264, 2011.

[30] H. Zouaïdia, G. de Bélair, M. Benslama, I. Soulié-Märsch,
S.D. Muller. Intérêt des Characeae comme bioindicateurs de la qualité des eaux: le cas des zones humides de Numidie (Nord-Est Algérien). Revue d'Ecologie (Terre et Vie), Vol. 70, 1-13, 2015.

[31] H. Van Dam, A. Martens, J. Sinkeldam. A coded checklist and ecological indicator values of freshwater diatoms from the Netherlands, Netherlands J. Aquatic Ecol., Vol.28, 117-133, 1994. 